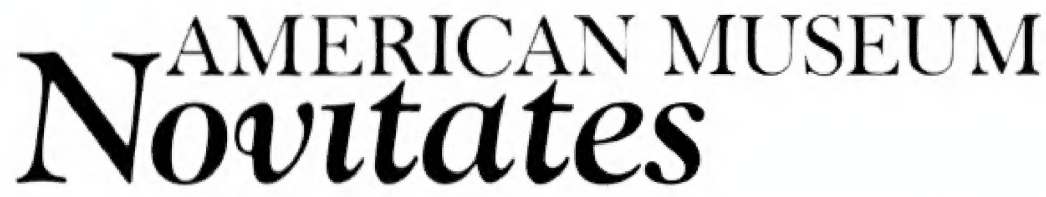

PUBLISHED BY THE AMERICAN MUSEUM OF NATURAL HISTORY
CENTRAL PARK WEST AT 79TH STREET, NEW YORK, NY 10024
Number 3332, 9 pp., 5 figures

\title{
Santonian Ammonites from the Blossom Sand in Northeast Texas
}

\author{
W.J. KENNEDY, ${ }^{1}$ N.H. LANDMAN,$^{2}$ AND W.A. COBBAN ${ }^{3}$
}

\begin{abstract}
The Blossom Sand is a lateral equivalent of the Austin Chalk Group, developed in Fannin, Lamar, and Red River counties in northeast Texas. Ammonites from this unit are Placenticeras syrtale (Morton, 1834), Baculites sp. cf. haresi Reeside, 1927, and Glyptoxoceras texanum, $\mathrm{n}$. sp. The general aspect of the Placenticeras assemblage suggests a late Santonian age for this unit.
\end{abstract}

\section{INTRODUCTION}

The term Blossom Sand was introduced by Gordon (1909) for what Veatch (1906) and others had termed the sub-Clarksville sand. The type locality is a well at Blossom, to the east of Paris, in Lamar County, Texas (fig. 1). The most comprehensive account of the unit remains that of Stephenson (1918). The unit reaches a thickness of up to $76 \mathrm{~m}$ (250 $\mathrm{ft}$ ) in the eastern part of its exposure where it rests on rocks assigned to the Bonham Formation (Barnes, 1966, 1967). Traced westwards, the formation thins and loses its char- acter, feathering out in Fannin County (Barnes, 1967).

The Blossom Sand was initially regarded as a lateral equivalent of part of the Cenomanian-Turonian Eagle Ford Group, but Stephenson (1918) demonstrated that it was equivalent to the Austin Chalk, and he suggested that the fauna indicated a correlation with the upper part of the Austin Chalk near Austin in Travis County, Texas. Subsequent authors (e.g., Young, 1963) regarded the unit as Santonian, but it remained imprecisely dated. Stephenson (1918) recorded Hamites, Baculites asper Morton, 1834, Placenticeras

\footnotetext{
' Curator, Geological Collections, University Museum, Parks Road, Oxford, OXI 3PW, U.K.

${ }^{2}$ Curator, Division of Paleontology (Invertebrates), American Museum of Natural History.

${ }^{3}$ Research Associate, Division of Paleontology (Invertebrates), American Museum of Natural History.
} 


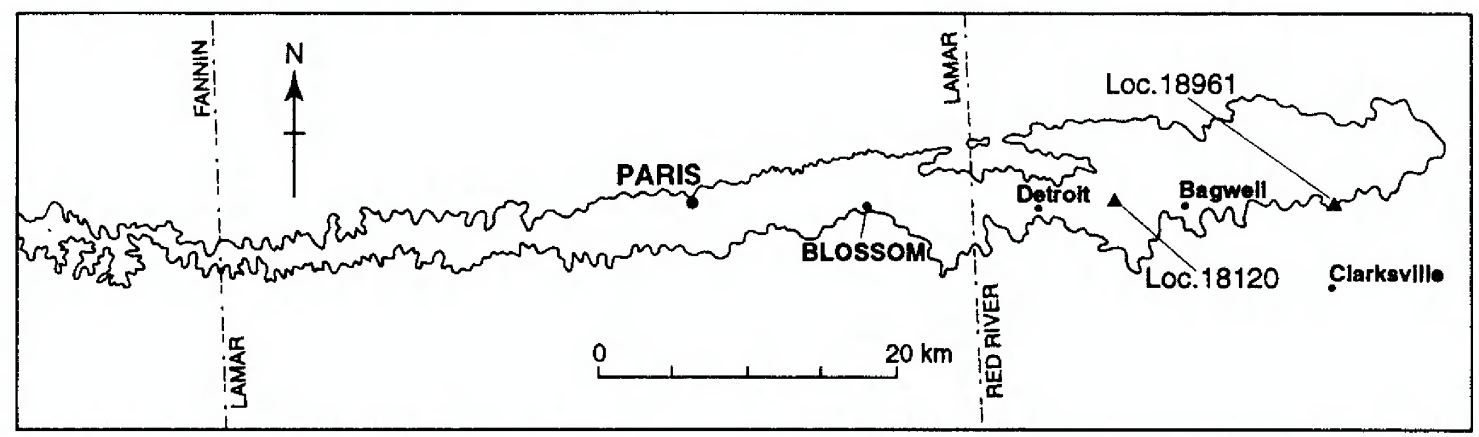

Fig. 1. The outcrop of the Blossom Sand in northeast Texas, showing the localities cited in the text.

sp., and Prionotropis?, but he did not illustrate these specimens, and their present whereabouts are unknown. In addition, most of his localities are no longer accessible. We describe below material from two new localities (fig. 1) that have been discovered since the work of Stephenson (1918): (1) USGS Mesozoic locality 18961: Blossom Sand, borrow pit just west of State Highway $37,6.6 \mathrm{~km}(4 \mathrm{mi})$ north of Clarksville, Red River County, Texas. Collected by L. W. Stephenson, 1944. This collection yields abundant Placenticeras syrtale (Morton, 1834) as well as rare Baculites sp. cf. haresi Reeside, 1927. (2) USGS Mesozoic locality 18120: Top of Blossom Sand between Detroit and Bagwell, Red River County, Texas. Collected by D. J. Flesh, 1939. This collection consists of two specimens of Glyptoxoceras texanum, n. sp.

The key to dating the Blossom Sand is Placenticeras syrtale. Wolleben (1967) analyzed changes in a succession of $P$. syrtale assemblages through the "Lower Campanian" interval in trans-Pecos Texas. Since this work, the International Sub-Commission on Cretaceous Stratigraphy has reached a preliminary decision on the definition of the base of the Campanian (see below), and the Placenticeras sequence studied by Wolleben appears to span the Santonian-Campanian boundary. The material from the Blossom Sand corresponds to the earliest subspecies of $P$. syrtale recognized by Wolleben, and it dates the unit as late Santonian.

\section{BASE OF THE CAMPANIAN}

The working party on the base of the Campanian Stage, meeting in Brussels in 1995 (Hancock and Gale, 1996), reached a preliminary decision that the base of the Campanian should be drawn at the extinction point of the widely distributed crinoid Marsupites. Gale et al. (1995) provided a detailed discussion of the relationship between this event and the various other datum-levels used to define this boundary, and they demonstrated that the extinction point of Marsupites in Texas occurs at the top of, or just within, the Submortoniceras tequesquitense Zone of Young (1963). It is in this sense that the base of the Campanian is applied in the present contribution.

Young (1963: 102) described the holotype (and only recorded specimen) of Submortoniceas vandalianense from "a Blossom lithology" that "may indicate a Blossom facies at a higher level than heretofore reported." This specimen appears to be from a different unit of a younger, Campanian age.

Fig. 2. Placenticeras syrtale (Morton, 1834). A-C. USNM 490961; D-F. USNM 490962; G-I. USNM 490963; J,K. USNM 490964; L, M. USNM 490965; N, O. USNM 490966. All specimens are from the Blossom Sand at USGS Mesozoic locality 18961 in Red River County, Texas. Arrows indicate the base of the body chamber. All figures are $\times 1$. 

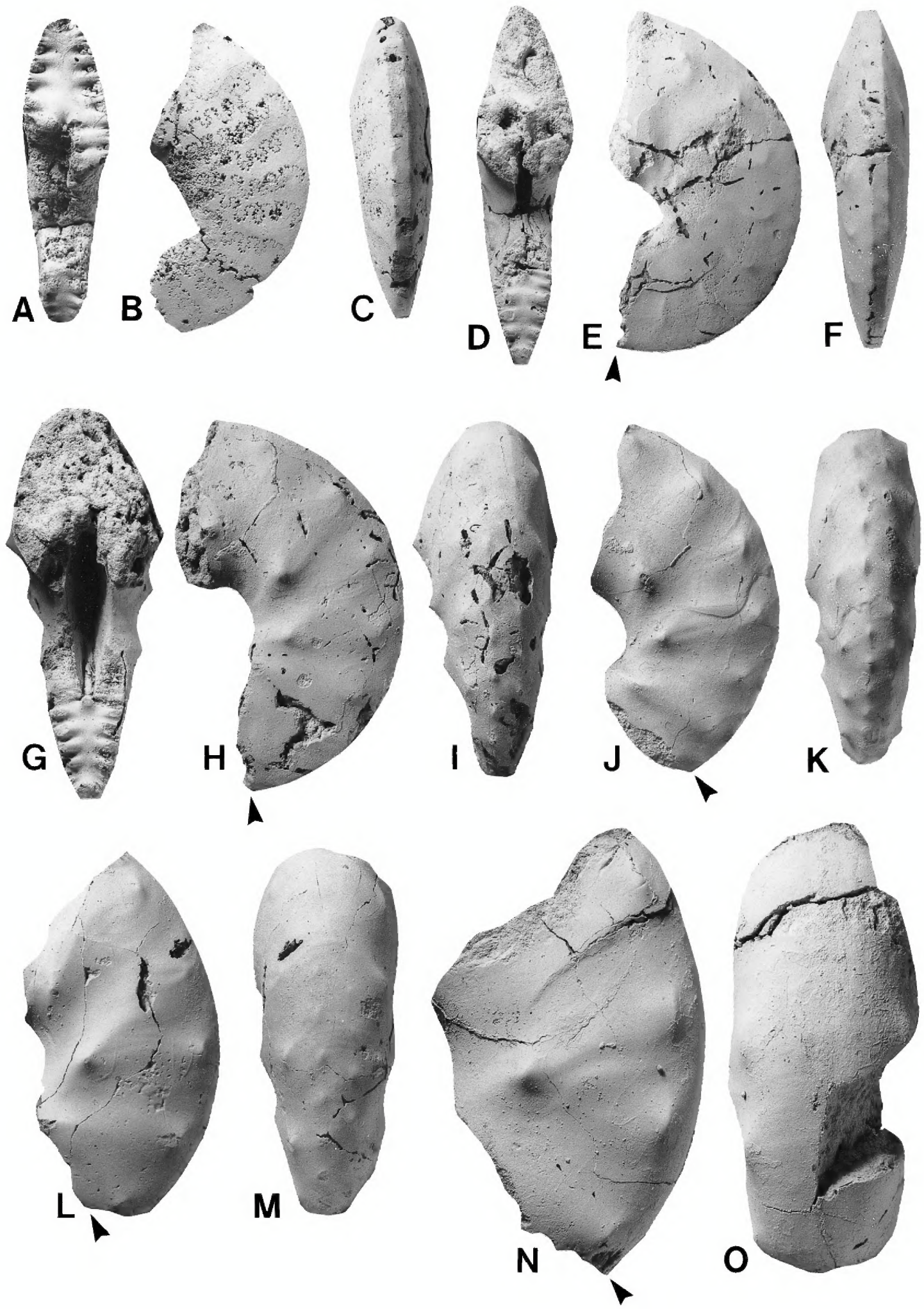


\section{SYSTEMATIC PALEONTOLOGY}

SUBORDER AMMONITINA HYATT, 1889

SUPERFAMILY HOPLITACEAE DOUVILLÉ, 1890

FAMILY PLACENTICERATIDAE HYATT, 1900

Genus Placenticeras Meek, 1876

Type SPECIES: Ammonites placenta Dekay, 1828: 278, pl. 5, fig. 2 (not 5).

\section{Placenticeras syrtale (Morton, 1834) \\ Figures 2, 3I-P}

Ammonites syrtalis Morton, 1834: 40, pl. 16, fig. 4. Stantonoceras pseudocostatum Johnson. Scott and Cobban, 1964: pl. 8.

Placenticeras syrtale (Morton, 1834). Wolleben, 1967: 1161 (with additional synonymy).

Placenticeras syrtale syrtale (Morton, 1834). Wolleben, 1967: 1161, pl. 150, fig. 5; pl. 151, figs. 1, 2, 5-7; text-fig. 7e, f.

Placenticeras syrtale adkinsi Wolleben, 1967: 1164 , pl. 151 , figs. 8 , 9; pl. 152, figs. 1, 2, 58; text-fig. 89.

Placenticeras syrtale rooneyi Wolleben, 1967: 150, figs. 6, 7; pl. 151, figs. 3, 4; pl. 152, figs. 3,4 ; text-fig. $7 \mathrm{~d}, \mathrm{~g}$.

Placenticeras (Stantonoceras) guadalupae Roemer. Cobban, 1976: 125, pl. 2, fig. 7.

Placenticeras syrtale (Morton, 1834). Kennedy and Cobban, 1991: 176, figs. 7.1-7.4, 11.5.

Placenticeras syrtale (Morton, 1834). Kennedy and Cobban, 1993: 835, figs. 5.4-5.6.

Placenticeras syrtale (Morton, 1834). Kennedy et al., 1995: pl. 2, figs. 1, 2.

TYPE: Holotype, by monotypy, is the original of Morton, 1834 (p. 40, pl. 16, fig. 4), from the "older Cretaceous" of Greene County, Alabama. It was refigured by Hyatt (1903: pl. 27, fig. 15; pl. 28, figs. 1, 2) and is no. 282 in the collection of the Academy of Natural Sciences of Philadelphia.

DESCRIPTION: There are 27 specimens, including USNM 490961-490969. Most specimens are juveniles, the majority of which are body chambers, with whorl heights ranging from 18 to $50 \mathrm{~mm}$. Specimens display a broad range of variation. In more compressed specimens, the ratio of whorl breadth to height is as low as 0.56 ; the coiling is very involute, with a tiny craterlike umbilicus. The umbilical wall and shoulder slope outward, with the greatest breadth just outside the umbilical shoulder. The inner flanks are feebly convex, the outer flanks are flattened and convergent, and the venter is very narrow and tabulate. Ornament consists of delicate falcoid ribs that form prominent crescentic ridges on the outer flank, and delicate ventral clavi that alternate across the venter, numbering around 20 per half whorl. As the whorl section becomes less compressed, the ornament coarsens. Low primary ribs strengthen across the umbilical wall and shoulder and form umbilicolateral bullae. These give rise to one or two low prorsiradiate ribs that are straight on the inner flank and concave on the outer flank, where they are joined by intercalated ribs, all of which form crescentic bullae on the outer flank (fig. $2 \mathrm{~A}-\mathrm{J})$. The ventral clavi are more numerous than the bullae. In the most robust specimens, the ratio of whorl breadth to height is as high as 0.8 ; the greatest breadth is at the umbilicolateral bullae. The flanks are convergent and the venter is broad and feebly convex. Coarse umbilicolateral bullae give rise to pairs of ribs, with prominent outer lateral nodes and ventral clavi that are two to three times as numerous as the nodes (figs. $2 \mathrm{~L}-\mathrm{O}, 3 \mathrm{~N}-\mathrm{P})$. The largest specimen has an estimated diameter of $110 \mathrm{~mm}$ and appears to be a microconch body chamber. It shows eccentric coiling and a decline in ornament over the last $90 \%$ of the body chamber.

Discussion: Kennedy and Cobban (1991: 175) discussed the temporal changes in the Gulf Coast Placenticeras syrtale lineage: "At any one stratigraphic level there is great intraspecific variation, and many names have been introduced for different morphological variants. . . Good illustrations of variation (and use of many names) are to be found in

Fig. 3. A-H. Baculites sp. cf. haresi Reeside, 1927. A-D. USNM 490972; E-H. USNM 490973; I-P. Placenticeras syrtale (Morton, 1834); I, M. USNM 490967; J-L. USNM 490968; N-P. USNM 490969. All specimens are from the Blossom Sand at USGS Mesozoic locality 18961 in Red River County, Texas. Arrows indicate the base of the body chamber. All figures are $\times 1$. 

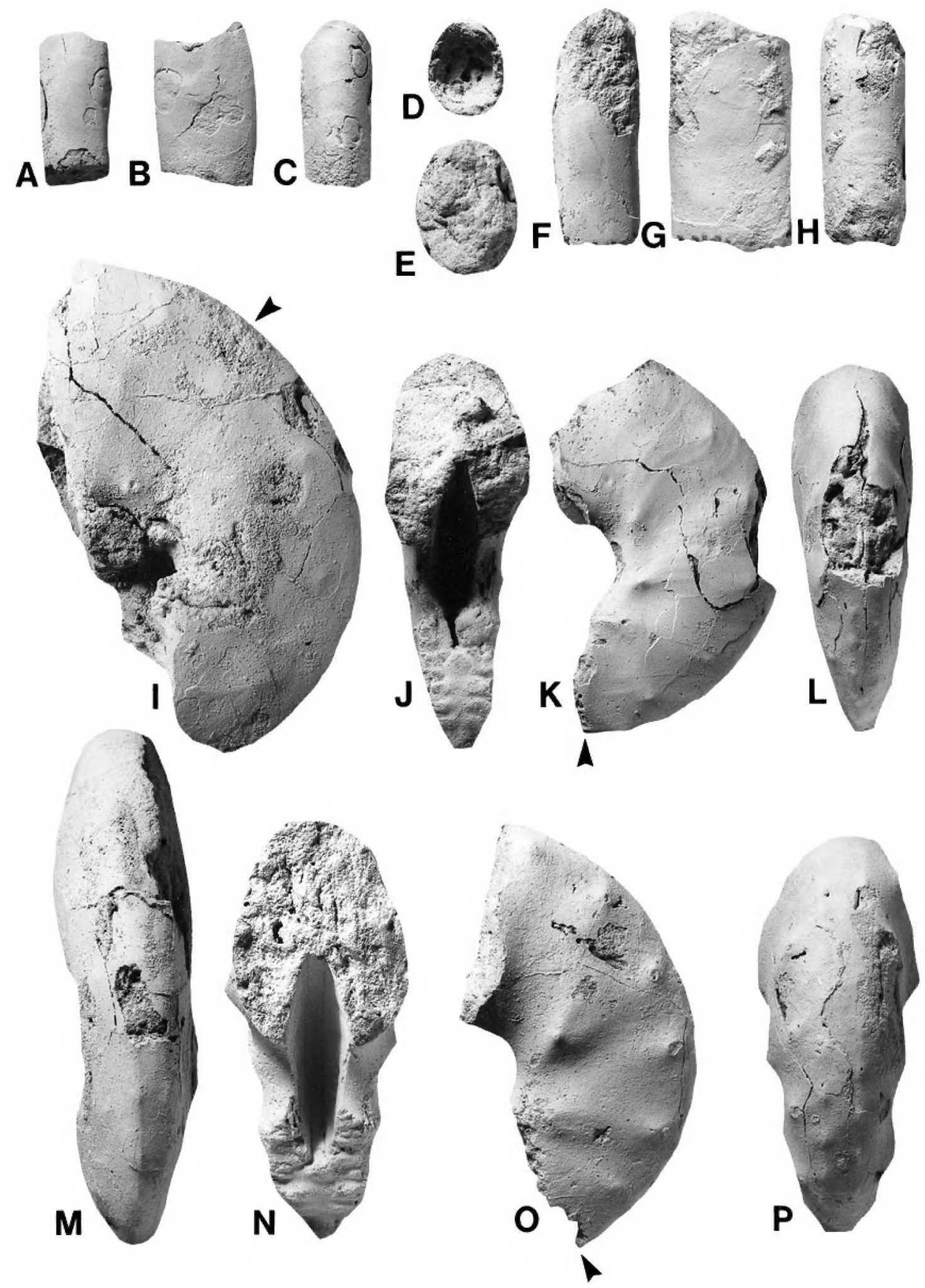

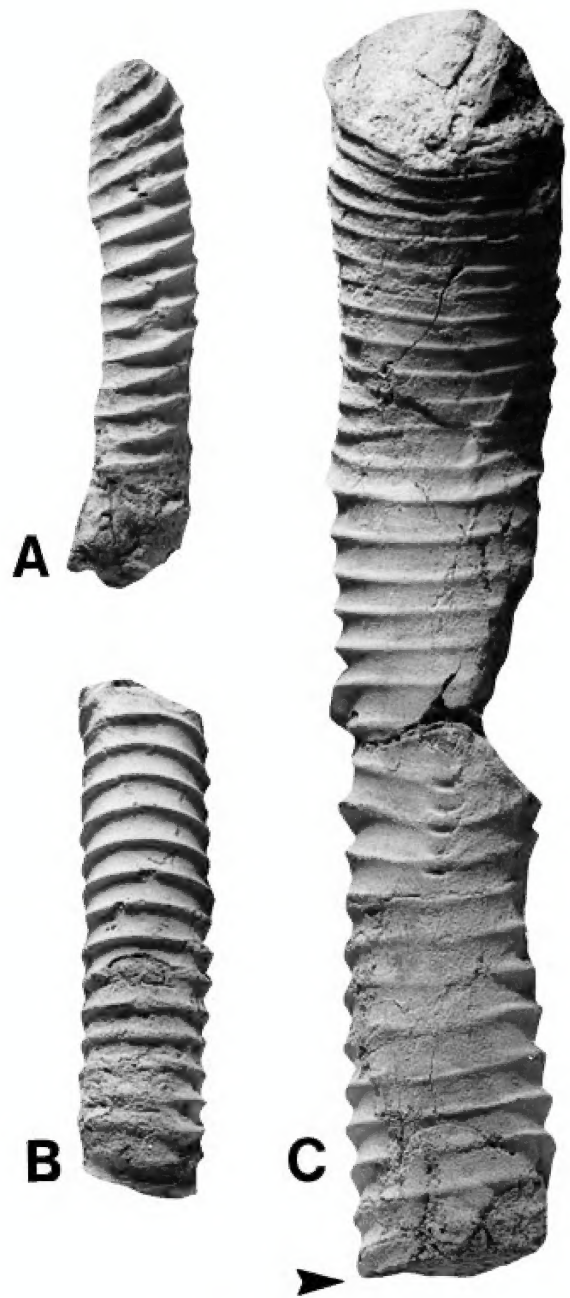
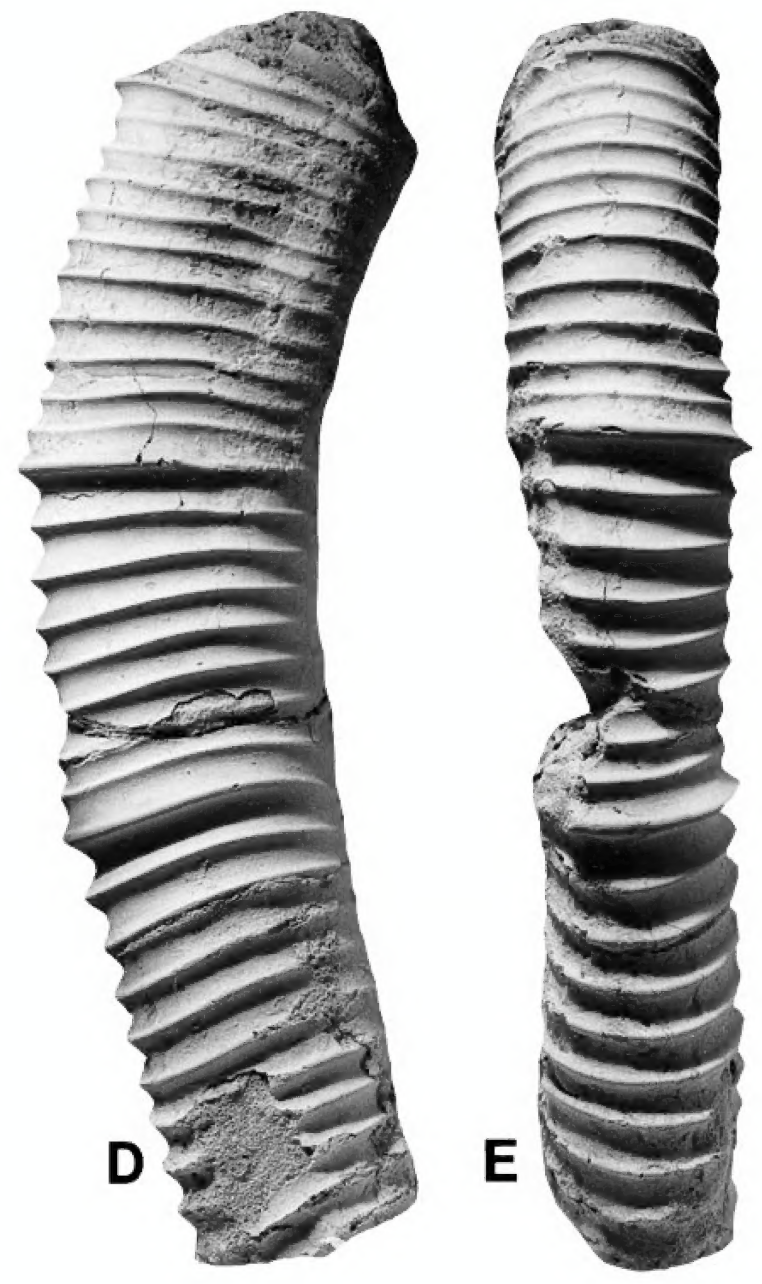

Fig. 4. Glyptoxoceras texanum, n. sp. A, B. Paratype USNM 490971; C-E. holotype, USNM 490970. Both specimens are from the Blossom Sand at USGS Mesozoic locality 18120 in Red River County, Texas. Arrows indicate the base of the body chamber. All figures are $\times 1$.

Hyatt (1903), Reeside (1927) and Young (1963). Wolleben (1967) is the latest to have tackled this group, studying a collection of over 600 specimens from the San Carlos and Ojinaga areas of Presidio County in TransPecos Texas and Chihuahua, Mexico, respectively. . . . He used the unidirectional trend of whorl height-umbilical node distance coefficients to divide what he termed the "polymorphic Placenticeras chronocline' into chronologic polymorphic subspecies." According to Wolleben Placenticeras syrtale syrtale (Morton, 1834) (upper Santonian to lower Campanian) is a subspecies that includes specimens corresponding to $P$. syrtale of previous authors, $P$. syrtale adkinsi Wolleben, 1967 (lower Campanian) is a subspecies that includes specimens corresponding to Placenticeras pseudosyrtale of previous authors, and P. syrtale rooneyi Wolleben, 1967 (lower Campanian) is a subspecies that includes specimens of Placenticeras newberryi of previous authors. Although Wolleben favored this approach to "avoid future nomenclature confusion" (Wolleben, 1967: 1161), it overlooks the principles of priority set out in the International Code of Zoological Nomenclature.

In the Blossom Sand assemblage, specimens range from compressed and feebly or- 
namented to less compressed and moderately strongly ornamented. They correspond to the earliest subspecies of Wolleben (1967). The incidence of weakly ornamented individuals is lower than that in the assemblage described by Kennedy and Cobban (1991) from the correlatives of the Santonian Texanites shiloensis Zone of Young (1963) in Mississippi, suggesting a higher level than this assemblage, but probably still within the Santonian as here defined.

OCCURRENCE: Blossom Sand at USGS Mesozoic locality 18961 . The species ranges from upper Santonian to lower Campanian, and is known from northern Mexico, Texas, Alabama, Mississippi, New Mexico, Colorado, Wyoming, Montana, and Utah.

\section{SUBORDER ANCYLOCERATINA WIEDMANN, 1966}

SUPERFAMILY TURRILITACEAE GILL, 1871

FAMILY DIPLOMOCERATIDAE SPATH, 1926

SUBFAMILY DIPLOMOCERATINAE SPATH, 1926

Genus Glyptoxoceras Spath, 1925

TYPE SPECIES: Hamites rugatus Forbes, $1846: 117$, by the original designation of Spath, 1926:81.

\section{Glyptoxoceras texanum, new species} Figure 4

Derivation OF NAME: From the state of Texas.

TYPE: Holotype is USNM 490970 (fig. 4C-E), paratype is USNM 490971 (fig. 4A, B), from the top of the Blossom Sand at USGS Mesozoic locality 18120, between Detroit and Bagwell, Red River County, Texas.

Diagnosis: A large species of Glyptoxoceras; body chamber bears rursiradiate ribs and periodic constrictions, each of which is flanked by a flared adapertural rib.

DESCRIPTION: The holotype USNM 490970 is a body chamber fragment $120 \mathrm{~mm}$ long, with replaced shell (fig. 4C-E). The maximum preserved whorl height is $31 \mathrm{~mm}$. The specimen has suffered some post-mortem crushing, but the whorl section of the uncrushed portion is compressed ovoid with the venter more narrowly rounded than the dorsum; the ratio of whorl breadth to height is 0.75 . For most of the length of the fragment, the ornament consists of coarse, narrow ribs; the rib index is 6 . The ribs are much narrower than are the interspaces; ribs are weak and transverse to feebly concave across the dorsum, stronger and convex across the dorsolateral margin, strong, straight, and rursiradiate on the flanks, and transverse on the venter, where they attain their maximum height. There are two broad, deep constrictions on the fragment, each of which is flanked by a flared adapertural rib. The adoral of these two constrictions is succeeded by a section of shell $40 \mathrm{~mm}$ in length on which the ornament changes markedly, indicating that the specimen is part of the terminal adult body chamber immediately prior to the final aperture. Ribbing is much finer, lower, and weaker, and the rib index increases to 11 . There is a weak constriction and flared rib immediately adapical of the aperture.

The paratype USNM 490971 is much smaller, $52 \mathrm{~mm}$ long, crushed, with a maximum preserved whorl height of $11 \mathrm{~mm}$ and whorl breadth of $13.5 \mathrm{~mm}$ (fig. 4A, B). The depressed whorl section is probably an artifact of post-mortem deformation. Ornament consists of narrow, distant ribs that are weak and feebly concave across the dorsum; they strengthen across the dorsolateral margin, where they are sharp and high and much narrower than the interspaces. The ribs are markedly prorsiradiate on the flanks and strong and feebly convex across the venter. The sutures are not exposed.

Discussion: The holotype of Glyptoxoceras ellisoni Young, 1963 (p. 46, pl. 1, figs. 10-14, 16-20; pl. 73, fig. 9; pl. 78, fig. 6) from the Dessau Chalk in central Texas is a body chamber fragment $125 \mathrm{~mm}$ long with a maximum preserved whorl height of $22 \mathrm{~mm}$ (fig. 5). It overlaps in size with the holotype of G. texanum but it has much coarser, blunter ribbing (even when the differences of preservation are taken into account), with a rib index of around 4; there are no constrictions. Glyptoxoceras rubeyi (Reeside, 1927) (p. 14, pl. 3, figs. 8-10; pl. 5, figs. 3-11) has much more widely separated and coarser ribs. The holotype of Glyptoxoceras novimexicanum (Reeside, 1927) (p. 8, pl. 4, figs. $1-4)$, a body chamber fragment that is comparable in size to the holotype of G. texanum, lacks constrictions. 

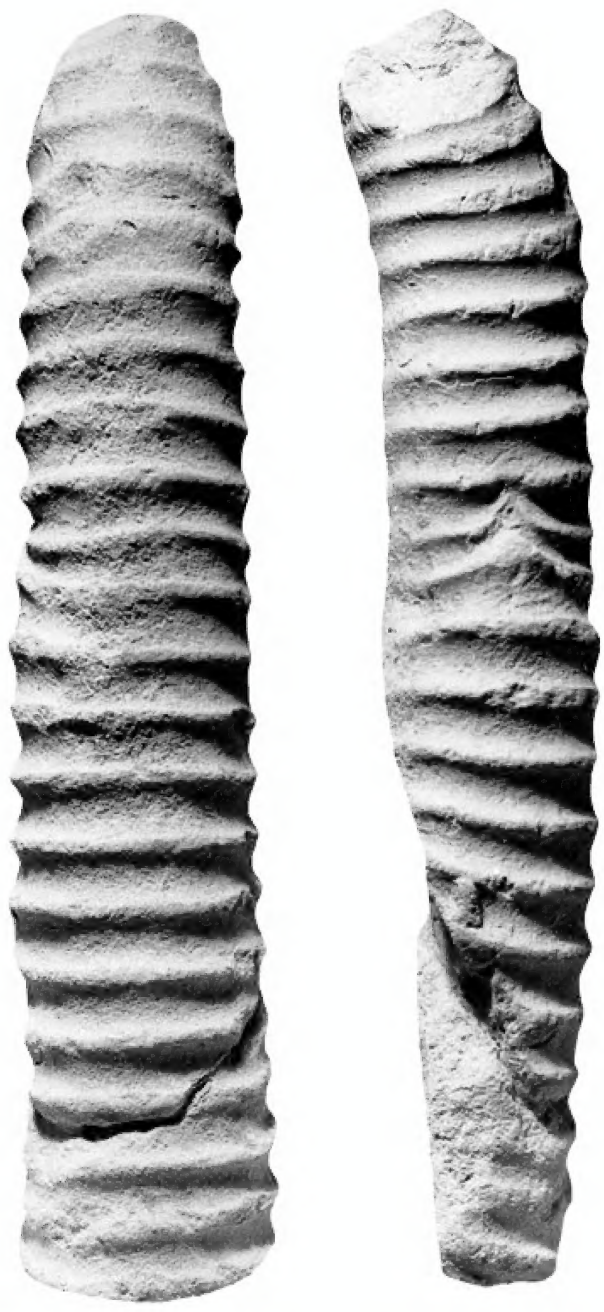

Fig. 5. Glyptoxoceras ellisoni Young, 1963. Holotype, Texas Memorial Museum Collections no. 182, from the Austin Chalk on Brushy Creek, $800 \mathrm{~m}(0.5 \mathrm{mi})$ south of Hutto, Williamson County, Texas. All figures are $\times 1$.

OCCURRENCE: As for type.

FAMILY BACULITIDAE GILL, 1871

Genus Baculites Lamarck, 1799

TYPE SPECIES: Baculites vertebralis Lamarck, 1801:103, by subsequent designation by Meek, 1876:391.

\section{Baculites sp. cf. haresi Reeside, 1927} Figure $3 \mathrm{~A}-\mathrm{H}$

cf. Baculites ovatus Say, 1820 var. haresi Reeside, 1927:10, pl. 6, figs. 5-10; pl. 7, figs. 9, 10.
DESCRIPTION: There are two body chamber fragments, USNM 490972 (fig. 3A-D) and USNM 490973 (fig. 3E-H). The latter has a maximum preserved whorl height of $20 \mathrm{~mm}$ and a ratio of whorl breadth to height of 0.74; the whorl section is ovoid and the dorsum is more broadly rounded than the venter. Both fragments are virtually smooth, with traces of delicate riblets and striae that are strongly prorsiradiate on the outer flank and cross the venter in a broad convexity (fig. $3 \mathrm{H})$.

Discussion: These fragments belong to a very generalized Baculites, and are most comparable to Baculites haresi Reeside, 1927 (e.g., pl. 6, figs. 5, 6).

OCCURRENCE: Blossom Sand at USGS Mesozoic locality 18961.

\section{ACKNOWLEDGMENTS}

We thank J. M. Hancock (Shaftesbury, U.K.), H.C. Klinger (Cape Town, South Africa), K. Tanabe (Tokyo, Japan), and R. H. Mapes (Athens, Ohio) for critical reviews of an earlier version of this manuscript. W.J.K. acknowledges the financial support of the Natural Environment Research Council (U.K.) and the technical support of the staff of the Geological Collections, University Museum, Oxford, and Department of Earth Sciences, Oxford. N.H.L thanks B. Worcester and S. Crooms (both AMNH) for help in preparation of the manuscript. The specimens were provided by the U.S. Geological Survey.

\section{REFERENCES}

Barnes, V. E.

1966. Geologic atlas of Texas, Texarkana sheet. Univ. Texas Bureau of Economic Geology, scale 1:250,000.

1967. Geologic atlas of Texas, Sherman sheet. Univ. Texas Bureau of Economic Geology, scale 1:250,000.

Cobban, W. A.

1976. Ammonite record from the Mancos Shale of the Castle Valley-Woodside area, east-central Utah. Brigham Young Univ. Geol. Stud. 22: 117-126.

Dekay, J. E.

1828. Report on several multilocular shells from the State of Delaware: with observations on a second specimen of the 
new genus Eurypterus. Lyceum Nat.

Douvillé, $\mathrm{H}$. Hist. 2: 273-279.

1890. Sur la classification des Cératites de la Craie. Bull. Soc. Géol. France (3), 18: 275-292.

Forbes, E.

1846. Report on the fossil Invertebrata from southern India, collected by Mr. Kaye and Mr. Cunliffe. Trans. Geol. Soc. London (2), 7: 97-174.

Gale, A. S., P. Montgomery, W. J. Kennedy, J. M.

Hancock, J. A. Burnett, and J. M. McArthur

1995. Definition and global correlation of the Santonian-Campanian boundary. Terra Nova 7 (for 1995): 611-622.

Gill, T.

1871. Arrangement of the families of Mollusks. Smithson. Misc. Collect. 227: xvi +49 pp.

Gordon, C. H.

1909. The chalk formations of northeast Texas. Am. J. Sci. (4), 27: 369-373.

Hancock, J. M., and A. S. Gale

1996. The Campanian Stage. Bull. Inst. R. Sci. Nat. Belgique, Sci. Terre 66 (suppl.): 103-109.

Hyatt, A.

1889. Genesis of the Arietidae. Smithson. Contrib. Knowl. 673: xi +239 pp.

1900. Cephalopoda. In K. A. Von Zittel (ed.), Textbook of palaeontology: 502-604. Transl. Eastman. London: Macmillan, 1896-1900.

1903. Pseudoceratites of the Cretaceous. U.S. Geol. Surv. Monogr. 44: 351 pp.

Kennedy, W. J., and W. A. Cobban

1991. Upper Cretaceous (upper Santonian) Boehmoceras fauna from the Gulf Coast region of the United States. Geol. Mag. 128: 167-189.

1993. Lower Campanian (Upper Cretaceous) ammonites from the Merchantville Formation of New Jersey, Maryland, and Delaware. J. Paleontol. 67: 828-849.

Kennedy, W. J., R. A. Johnson, and W. A. Cobban

1995. Upper Cretaceous ammonite faunas of New Jersey. In J.E.B. Baker (ed.), Contributions to the paleontology of New Jersey: 24-55. Geol. Assoc. New Jersey.

Lamarck, J. P. B. A. de M. de

1799. Prodrome d'une nouvelle classification des coquilles. Mém. Soc. Hist. Nat. Paris. (1799): 63-90.

1801. Système des animaux sans vertebrès. Paris: The author, vii $+432 \mathrm{pp}$.
Meek, F. B.

1876. A report on the invertebrate Cretaceous and Teritary fossils of the upper Missouri country. U.S. Geol. Surv. Territ. Rep. (Hayden) 9: lxiv + 629 pp.

Morton, S. G.

1834. Synopsis of the organic remains of the Cretaceous group of the United States. Illustrated by nineteen plates, to which is added an appendix containing a tabular view of the Tertiary fossils discovered in America. Philadelphia: Key and Biddle, 88 pp.

Reeside, J. B., Jr.

1927. The cephalopods of the Eagle Sandstone and related formations in the western interior of the United States. U.S. Geol. Surv. Prof. Pap. 151: 40 pp.

Say, T.

1820. Fossil zoology. Am. J. Sci. 1st Ser. 2(4): 34-45.

Scott, G. R., and W. A. Cobban

1964. Stratigraphy of the Niobrara Formation at Pueblo, Colorado. U.S. Geol. Surv. Prof. Pap. 454-L: L1-L27.

Spath, L. F.

1925. On Senonian Ammonoidea from Jamaica. Geol. Mag. 62: 28-32.

1926. On new ammonites from the English Chalk. Geol. Mag. 63: 77-83.

Stephenson, L. W.

1918. A contribution to the geology of northeastern Texas and southern Oklahoma. U.S. Geol. Surv. Prof. Pap. 120-H: 129-163.

Veatch, A. C.

1906. Geology and underground water resources of northern Louisiana and southern Arkansas. U.S. Geol. Surv. Prof. Pap. 46: 422 pp.

Wiedmann, J.

1966. Stammesgeschichte und System der posttriadischen Ammonoideen; ein Überblick. Neues Jahrb. Geol. Paleontol. Abh. 125: 49-79; 127: 13-81.

Wolleben, J. A.

1967. Senonian (Cretaceous) Mollusca from Trans-Pecos Texas and northeastern Chihuahua, Mexico. J. Paleontol. 41: 1150-1165.

Young, $\mathrm{K}$.

1963. Upper Cretaceous ammonites from the Gulf Coast of the United States. Univ. Texas Bull. 6304: ix +373 pp. 
Recent issues of the Novitates may be purchased from the Museum. Lists of back issues of the Novitates and Bulletin published during the last five years are available at World Wide Web site http://nimidi.amnh.org. Or address mail orders to: American Museum of Natural History Library, Central Park West at 79th St., New York, NY 10024. TEL: (212) 769-5545. FAX: (212) 7695009. E-MAIL: scipubs@amnh.org

(2) This paper meets the requirements of ANSI/NISO Z39.48-1992 (Permanence of Paper). 